\title{
På jorden
}

\section{ANMELDELSE}

\section{Nordisk kvindelitteraturhistorie 4, På jorden.}

Munksgaard \& Rosinante.

København 1997

597 s., 698 kr.

\section{ANMELDT AF}

ANNEMETTE HEJLSTED

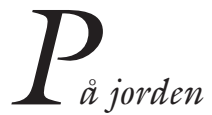

er titlen på Nordisk kvindelitterturhistories fjerde bind. Værket omhandler vor samtids litteratur, nærmere betegnet tiden fra 1960 til 1990, og rummer alle de problemer, der er ved at skrive sin samtids litteraturhistorie. Hvordan samle tendenser, når tidsafstanden er lille? Hvordan analysere problemstillinger, man selv har været part i? etc. I det store hele kommer litteraturhistoriens forfattere og redaktører godt fra det. Og det gør de ikke mindst i kraft af, at hver enkelt artikel er signeret og herved fremstår som den enkelte skribents version og tolkning af de respektive forfatterskaber.

På jorden falder i tre hoveddele, hvor den første udgøres af hovedafsnittene "Fornyelser" og "Forandre sproget", der overordnet set fungerer som en art diagnosticering af kvinders litteratur i 60'erne og frem til kvindebevægelsen og rødstrømpebevægelsen i 70'erne. Her fokuseres på kritikken af den mandsdominerede kultur og fremvæksten af nye udtryksformer under modernismens primat. Retfærdigvis skal det understreges, at de enkelte forfatteres 
spændvidde og individuelle udvikling pointeres.

70’ernes køns- og kvindebevidste tidsånd er udgangspunktet for den store midterdel. I "Bevæge verden" er det de individuelle positioner i den allestedsnærværende diskussion om kvinders livsverden og muligheder, der er i fokus. Det billede, der tegnes af litteraturen, svarer et langt stykke af vejen til alle fordommene om dens egenart. Æstetisk set er den præget af bekendelseslitteratur og knækprosa, tematisk af kritikken af umulige livsbetingelser og bestræbelsen på frigørelsen fra dem. I kraft af detaljeringen i præsentationen af de enkelte forfatterskaber og mangfoldigheden af dem tegner der sig et dybt og mangefacetteret billede, der viser, at variation og kvalitet kan ligge $\mathrm{i}$ et finmasket net af diminutive forskelle

"Blive sig selv" kaldes sidste del, der har 80 'ernes og 90'ernes litteratur som emne. Her sprænges de spor af tematiske enhed, der eksisterede i kvindefrigørelsens årti. Tematiseringen af kvinders livsvilkår forskydes til tematiseringen af køn og det menneskelige. Derfor står kvinderne ikke længere på sidelinjen. Med et citat af Solvej Balle hedder det uden omsvøb: Kvinderne kan ikke langere sige, at de stair udenfor. At det er mandenes ansvar. Vi mà deltage i forsøget pà at finde ud af, hvad det er at vere menneske. (Solvej Balle, Weekendavisen 1.-7. oktober 1993 (På jorden s. 544)). Nyorienteringen i de rstetiske udtryksformer følger trop. Den fremstilles som et festfyrværkeri af genreoverskridelser, hybrider og intertekstualitet, der ikke lader noget tilbage for 60'ernes modernistiske formeksperimenter.

Værkets finale udgøres af et afsnit om "Oprindelige folk", hvori den grønlandske og samiske kvindelitteraturs opkomst og udvikling fremstilles. På en måde bliver skildringen af disse unge litteraturer og de kvindelige forfattes kamp for at få en plads i deres kultur og litteratur et stærkt og syntetiseret billede på hele den udvikling, som den nordiske kvindelitteratur har gennem- gået. Fremstillingen af disse eksotiske litteraturer, der på mange måder er præget af andre problemstillinger, rummer således sin helt egen pointe og er en værdig konklusion på et meget stort og vellykket projekt.

Anskues $P a ̊$ jorden lidt fra oven, ligger vægten i fremstillingen utvivlsomt på tematikkerne omkring de kvindelige livsvilkår og kvinders forhold til sig selv, deres elskere, ægtemænd, fædre, sønner, mødre, døtre, veninder etc. $\mathrm{Og}$ det er udviklingen inden for disse, der udgør plottet i det aktuelle bind af Nordisk kvindelitteraturhistorie. Fra undertegnedes synsvinkel tegner der sig en bevægelse fra en kritik af livsvilkårene over til en kamp for ændringen af dem til en erkendelse af, at vilkårene dybest set både gælder for mænd og kvinder. Baggrunden for denne udvikling fremstår som uforklaret. På jorden er meget karrig med at præsentere sammenhængen mellem den samfundsmæssige og kulturelle udvikling generelt og ændringerne i tematikkerne omkring kvindelighed og køn. Dette gør desværre værket indforstået med den gruppe læsere, der har gennemlevet hele perioden som voksne. Andre og yngre læsere med mindre kendskab til kønnenes historie i sidste halvdel af det 20. århundrede kan måske få svært ved at forstå, hvorfor kvindelige forfattere drejer opmærksomheden fra det kvindelige og egne til det fælles i 80'erne.

Forvandlingerne og linjerne i de xstetiske udtryksmidler står lige så uformidlet. I de forste dele af $P a ̊$ jorden træder de primært frem igennem portrætteringen af de enkelte forfatterskaber. Og de små indledende afsnit om modernismen hos de kvindelige forfattere forbinder ikke rigtig de kvindelige forfattere til traditionen og placerer dem i en position overfor den. Lidt klarere bliver det i midterdelen, hvor enkelte tidstypiske genrer fremhæves bl.a. dokumentarismen og den historiske roman. Til sidst bliver det rigtig godt. Da Anne-Marie Mai overtager styringen af de store linjer i afsnittet om 80'erlitteraturen, dukker det store overblik op. De spinkle tråde i den fo- 
regående fremstilling vindes til et stærkt garn, når hun accentuerer bruddene med den foregående litteratur. På jorden og hermed den historiske del af Nordisk kvindelitteraturhistorie ender således et indsigtsfuldt sted.

At læse blot et bind af en litteraturhistorie fra den ene ende til den anden ende er og forbliver en kunstig sag, der kun tilfalder én få gange i livet. Og derfor er forventningen om enhed og kontinuitet et skud på stolpen. I praksis er litteraturhistoriens primære funktion opslagsværkets, og det stiller helt andre krav. Det der søges er konkret viden og indgange til perioder, forfatterskaber, værker, temaer og genrer. Og som opslagsværk fungerer fjerde bind af Nordisk kvindelitteraturhistorie eminent. Mængden af behandlede forfatterskaber er i sig selv en kvalitet. Valget af fremstillingsform en endnu større: De enkelte artikelforfattere har bestræbt sig på at tegne et portræt af hvert forfatterskab uanset, hvor lav en prioritet det end har fået i den samlede fremstilling. Ofte tager portrætteringen udgangspunkt i et enkelt centralt værk, hvortil de andre relateres. Dette er godt, fordi læseren spares for både fuldstændig ligegyldige biografiske fremstillinger og værkopremsninger. Således står forfatterens idé og litterære fremstillingsmåde konsekvent i centrum.

Trods min fremførte skepsis overfor fremstillingen af enkelte linjer i Nordisk kvindelitteraturhistories fjerde bind mener jeg, at nordisk litteratur- og kønsforskning står overfor en milepæl. Vi har fået et fælles værk om en betragtelig del af vores litteratur, der ville have være usynlig uden kvindebevægelse og kvindeforskning. Som litteraturforskning viser værket, at nært tematisk fællesskab ikke er ensbetydende med enshed, som kønsforskning, at der stadig er bevægelser i forestillingerne om kvindelighed og køn. Men først og fremmest er vi blevet forsynet et gedigent værktøj, hvis holdbarhed ikke kan drages i tvivl.

Annemette Hejlsted ph.d.og mag.art., $K U$ 


\section{Myte og liv til døden os skiller - anmeldelse af to biografier om Tove Ditlevsen}

\section{ANMELDELSE}

Jens Andersen

Til døden os skiller

Gyldendal, København, 1997

288 s. $275,-\mathrm{kr}$.

Karen Syberg

Tove Ditlevsen. Myte og liv

Tiderne Skifter, Viborg. 1997 389 s. $325,-$ kr.

\section{ANMELDT AF}

Pernille Lomholt



i disse år megen hyldeplads hos boghandlerne. Der findes snart ikke den offentlige eller halv-offentlige person, som enten fremstiller sig selv eller bliver fremstillet af andre. Karen Sybergs: Tove Ditlevsen. Myte og liv (1997), og Jens Andersens: Til døden os skiller (1997) er heller ikke nogen undtagelse, bortset fra, at Tove Ditlevsen stort set har været glemt af den etablerede litterære verden i 20 år. Der er f.eks. ikke udgivet noget større værk om hendes forfatterskab før disse to biografier og det på trods af, at hun er en af de mest læste danske kvindelige forfattere $\mathrm{i}$ det tyvende århundrede

Karen Sybergs og Jens Andersens tilgange til stoffet har et biografisk udgangspunkt, hvilket er en tilbagevenden til den ellers gennem nykritikken og modernismen så udskældte biografiske metode. Det er da også med nogen mistro, at jeg som læser, der er opdraget med forestillingen om, at en tekst står for sig selv og ikke må sættes i forbindelse med den biografiske forfatter, går igang med de to biografier om Tove Ditlevsen. I Karen Sybergs og Jens Ander- 
sens værker bruges forfatterens fiktive (og selvfølgelig også hendes faktiske erindringer) til at forklare og uddybe følelser, hændelser og handlinger i hendes liv. Det er en metode, der virker stærkt ved læsningen, fordi den kunstneriske brug af sproget, som skønlitteraturen indeholder, på sin egen stille chokerende facon fremhæver de voldsomme oplevelser, som karakteriserer Ditlevsens eget liv. Der kan med afsæt i Tove Ditlevsens egne udtalelser argumenteres for, at den biografiske metode er den eneste rigtige at bruge $\mathrm{i}$ forhold til hende og hendes værker. Forfatteren siger i forordet til sin bog: Tove Ditlevsen om sig selv (1975): “Det er lige så umuligt at vurdere det (eget forfatterskab e.n.) sagligt som at se sig selv i øjnene uden spejl. Desuden ville for mit vedkommende en adskillelse af liv og digtning føles urimelig (...)" (Ditlevsen 1975: 5) Trods denne udtalelse skal en sammenkædning af forfatterskab og personligt liv tages med et vist forbehold, fordi Ditlevsen arbejder med et personligt sandhedsbegreb, der består $i$, at det enkelte menneske har sin egen oplevelse af virkeligheden, og at ingen kan fortælle sandheden om et andet menneske. Det betyder, at hendes fiktive personer altid er opbygget af elementer fra det virkelige liv, uden at der nødvendigvis kan sættes lighedstegn mellem f.eks. den unge Tove i Hedebygade og Ester fra Barndommens Gade (1943). Disse forbehold er begge forfattere opmærksomme på i deres læsning, men det kan til tider være svært at skelne fiktionen fra fakta $i$ analyserne af Tove Ditlevsens liv.

En forskel på de to biografier, der viser sig allerede ved en sammenligning af indholdsfortegnelserne, er værkernes komposition eller opbygning. Syberg går kronologisk frem fra barndom til døden i 1976. Andersen vælger det, han kalder en kalejdoskopisk model, hvor emnet selv vælger sin orden alt efter, hvorfra det anskues. Det betyder, at han begynder i 1940 og slutter i 1976. I løbet af gennemgangen og fortolk- ningen af det voksne liv vendes der tilbage til barndommen for dels at forklare og dels at perspektivere fremad. Derfor er det f.eks. først ved gennemgangen af årene 1965-68, hvor Tove Ditlevsen skriver sine erindringer, at Andersen går ned i en grundig analyse af forholdet til forældrene og i særdeleshed moderen. Andersen placerer, til forskel fra Syberg, Victor Andreasen (Ditlevsens fjerde xgtemand) som det centrale omdrejningspunkt i Ditlevsens liv. Det er forst midt i gennemgangen af forfatterens liv, at sammenhængen mellem Andreasen og moderen for alvor trækkes frem og behandles. Et noget sent tidspunkt når man tænker på, at moderen optræder på allerførste side i Tove Ditlevsens egne erindringer og dermed får en særdeles central placering i Ditlevsens forfatterskab.

Syberg koncentrerer sig allerede fra begyndelsen af sin biografi om Tove Ditlevsens forhold til moderen. Et forhold som, hun mener, er styrende for resten af forfatterens liv, særligt $\mathrm{i}$ forhold til Victor Andreasen. Syberg når frem til, at forholdet til moderen kan beskrives som et spørgsmål om magt eller opmærksomhed overfor ikke-opmærksomhed: "Angsten for den sorg, det er at miste moderens kærlighed, fører til ønsket om, at moderen i stedet skal miste hende, så sorgen kan blive Alfridas i stedet for Toves" (Syberg 1997: 46). Det vil med andre ord sige, at Tove Ditlevsen søger moderens kærlighed eller opmærksomhed, og når moderen ikke vil give den til hende, kan den lille pige vende sig ind i sig selv og lege med ord i sit sind. Derved kan moderen ikke længere nå hende. Tove Ditlevsen "vinder", fordi hun på denne måde i det mindste opnår opmærksomhed fra moderen.

Syberg beskriver udviklingen af det, hun kalder forfatterens særlige psykiske økonomi, der kulminerer i ægteskabet med Victor Andreasen, et parforhold der sidestilles med mor-datter forholdet. Denne psykiske økonomi kommer eksplicit til udtryk i Tove 
Ditlevsens selvmordsforsøg og endelig i den gennemførte handling i 1976. Regnskabet består i, at Ditlevsen sørger over Victor Andreasen, særligt efter han for stedse har forladt hende i 1971. Hun påfører ham sin sorg ved at tage sit eget liv, derved, mener Syberg, træder Ditlevsen ud af forholdet som den vindende part.

Et særligt træk ved Andersens biografi er hans forklaring af Ditlevsens forhold til barnet i sig selv og dermed til hendes egne børn. Andersen mener, at Ditlevsen livet igennem bevarer barnet i sig selv, og da hun op gennem 1960'erne får det stadig psykisk dårligere, optager barnet $\mathrm{i}$ hende mere og mere plads, derfor rummer hun ikke længere plads til sine egne børn. Tove Ditlevsen mister med andre ord grebet og formår ikke længere at være voksen og forælder. Hun resignerer og trækker sig ind i sig selv for at skabe sit private værelse med plads til at skrive. Andersen viser denne resignation ved hjælp af illustrationer gennem biografien. Tove Ditlevsen fremstår som den attraktive unge kvinde, der i begyndelsen af 1940'erne er med på skiftende moder. Senere i 1950'erne er hun den hjemmegående husmor, der stadigvæk følger moden, men her anes et begyndede forfald til den person af nærmest intetkøn, som Ditlevsen viser frem i begyndelsen af 1970'erne. Hendes fysiske og psykiske forfald holdes ikke længere skjult, tværtimod udstiller hun sin tilbagetrækning fra livet, tilbage mod barnet og døden.

Syberg forsøger i sin biografi, at stille sig mellem myten og livet, hvilket betyder, at hun med biografien prøver at nedbryde nogle af myterne omkring Tove Ditlevsen. Et eksempel på en myte er Ditlevsens beskrivelser af den fattigdom, hun oplever i 1920'erne. Syberg tilbageviser, ved hjælp af en gennemgang af moderens minutiøse husholdningsregnskaber, at familien under faderens arbejdsløshedsperioder levede af kaffe og gammelt wienerbrød. Syberg når ved hjælp af gennemgangen af regnskaberne frem til den konklusion, at beskrivelserne af fattigdommen i erindringerne må skyldes forfatterens dybtliggende angst for fattigdom, en angst der har fået hende til at fortætte og sammenfatte nogle følelser til oplevelser i barndommen.

Dette forsøg på at nedbryde en af myterne om forfatteren ved at inddrage kilder udenfor forfatterskabet kan kritiseres for at være unødvendig og i værste fald useriøst, eftersom forfatterskabet indeholder oplysninger og forklaringer nok i sig selv. Men omvendt er denne indragelse af andre kilder, som et supplement til Tove Ditlevsens egne, med til at krydre og perspektivere læsningen yderligere.

Jens Andersen benytter ikke andre kilder end Tove Ditlevsens egne. Men i modsætning til Syberg bruger han andre af forfatterens egne kilder, f.eks interviews og svar på læserbreve fra Familie Journalen. Disse kilder er med til at understrege sandhedsværdien i de egentlige erindringer, men bringer ikke noget nyt på banen som sådan.

Titlen på Andersens biografi: Til døden os skiller, henviser til Tove Ditlevsens særlige for hold til litteratur, familieliv og xgteskab, forhold der var særdeles skabende, men som også måtte gøre en ende på forfatterens liv. Det er forholdet til døden, som Jens Andersen trækker frem i begyndelsen af biografien, derved rettes fokus mod forfatterens endeligt.

Titlen på Karen Sybergs biografi: Tove Ditlevsen. Myte og liv, henviser til et gennemgående forsøg på at stille sig mellem myten og livet, hvilket fjerner den fokus på døden, som Andersen har. Syberg giver i sine overvejelser over forfatterens særlige psykiske økonomi en udmærket og spændende ramme til at forstå Tove Ditlevsens vanskelige sind og hendes handlinger på en ny måde.

Begge biografier er spændende, informerende og givende læsning for både kendere og ikke-kendere af Tove Ditlevsen og hendes forfatterskab. Værkerne er desuden af 
en sådan kvalitet, at de begge kan læses i en seriøs og i en mindre seriøs sammenhæng f.eks. på sofaen, hvilket ikke er et minus, men snarere et plus for en biografi.

Pernille Lombolt cand.mag.
Andersen, Jens (1997): Til døden os skiller. Gyldendal, København.

Ditlevsen, Tove (1975): Tove Ditlevsen om sig selv. Gyldendal, København.

Syberg, Karen (1997): Tove Ditlevsen. Myte og liv. Tiderne Skifter, Viborg. 


\section{Feberens ville rose}

\section{ANMELDELSE}

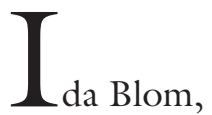

som er nordens eneste professor i kvindehi-

Ida Blom

Feberens ville rose

Tre omsorgssystemer i tuberkulose-

arbeidet 1900-1960

Fagbokforlaget, Bergen, 1998

179 s., 228 ,- N.kr

storie, vil med sin bog give et bidrag til den senere tids forskning om velfærdsstatens opkomst og især se på, hvilken rolle kvinder har spillet i den sammenhæng. Det prisme, som hun ser emnet igennem, er tuberkulosebekæmpelsen i Bergen. En frivillig kvindeforening fra 1890'erne, der oprindelig var blevet grundlagt for at skaffe sanitære hjælpemidler til brug i forbindelse med en eventuel krig (mod Sverige) eller en anden katastrofe, blev fra år 1900 en af hovedaktørerne i kampen mod tuberkulosen. Foreningens forhold til såvel det offentliges som andre frivillige foreningers bekæmpelsesarbejde undersøges for at finde mønstre $\mathrm{i}$ samarbejdet og i de sjældne konflikter - også dem mænd og kvinder imellem. Ida Blom vil vise, hvordan dette komplicerede partnerskab kæmpede for at begrænse og siden eliminere folkesygdommen ud fra samtidens viden om den. Elimineringen var lykkedes i 1960, da nye tilfælde var blevet en sjxldenhed.

I syv kapitler giver Ida Blom en grundig empirisk fremstilling af tuberkulosebekæm- 
pelsen. Først tegnes et billede af den generelle situation vedrørende sygdommen, hvis årsag, tuberkelbacillen, lige var blevet opdaget. Vi hører om sygdommens kliniske forløb, dens behandling, hyppighed og antal dødsofre. Dernæst påvises $\mathrm{i}$ alt fire omsorgssystemer: Det uformelle omsorgssystem, som foregik i hjemmene og især krævede husmoderens indsats; det officielle system, som fandtes hos staten og kommunen, og det frivillige, som blev varetaget af selvbestaltede foreninger, der havde tuberkulosebekæmpelsen som formål. Det sidste system var det såkaldt "kommercielle", som tjente på tuberkulosen vha. private sanatorier. Dette behandles ikke nærmere.

Sygdommen bliver set med de syges øjne. Således er kildegrundlaget skønlitterære tekster med deres eufemismer, et realistisk digt og erindringer fra en af de angrebne. Vi oplever samfundets stigmatisering af den syge og de lidelser, der fulgte heraf for familien i form af en ofte håbløs økonomi, når det var forsørgeren, der var blevet ramt, og af de meget store krav husmoderen da blev stillet overfor. Beskrivelsen af omsorgen i det uformelle system fører os bl.a. ind i de usle arbejderboliger. Her som overalt var det husmoderens ansvar at sørge for den absolut påkrævede renlighed, den personlige såvel som boligens. Det var bestemt ikke nemt, da mange huse endnu ikke havde indlagt vand. Et andet problem var det almindelige spytteri. I forsøget på at komme dette til livs, prøvede man at lære den tuberkuloseramte at bruge spytteflaske. Det uformelle omsorgssystem var afgjort det vigtigste både med hensyn til det forebyggende og det bekæmpende arbejde, derfor satte de to andre systemer mange kræfter ind på at oplyse og påvirke husmødrene.

Det offentlige omsorgssystems tyngdepunkt er tuberkuloseloven af år 1900, der indførte anmeldelsespligt for lægerne og tillod tvangsindlæggelse, hvilket må siges at være to meget håndfaste bestemmelser. Byernes sundhedskommissioner tog da efter anmeldelse ud til den syge med desinficeringsudstyr og oplysningspjecer. Staten og kommunen deltog i en lang række finansieringer af sanatorie- og hospitalsophold og ydede også anden økonomisk støtte. Kampen mod tuberkulosen var her uafhængig af partitilhørsforhold, men blev dog hovedsageligt varetaget af mænd.

Det frivillige omsorgssystem i Bergen udgjordes af organisationer som Norske Kvinders Sanitetsforening (NKS) fra år 1900 og Nasjonalforeningen mot Tuberkulosen (Nasjonalforeningen (NF)) fra 1910, og Røde Kors, der dog kun spillede en mindre rolle. NKS er bogens hovedaktør, hvorfor dens første år indenfor tuberkulosebekæmpelsen og dens hovedpersoner da også får en større plads i beskrivelsen. Vigtigt er at fremhæve, at den så godt som udelukkende bestod af borgerkvinder og havde en læge til formand. Hvis disse kvinder havde et politisk ståsted, så var det i partiet Venstre. Foreningens arbejde var blandt andet at oplyse det uformelle system og fremskaffe mælk. Derudover oprettede den sine egne sanatorier samt et børnehjem og et arbejdshjem - begge slags de første af deres art i Norge. Arbejdshjemmet eksemplificerer klart det filantropiske princip, at yde hjælp til selvhjælp: Opholdet på det var tænkt som overgangshjælp til kvinder, der kom fra sanatoriets liggestol og skulle tilbage til den hårde hverdag, noget mange tuberkuløse havde svært ved at klare. Børnehjemmet skulle beskytte de børn, hvis mødre var blevet syge, mod smitte. En feriekoloni blev oprettet og storstilede pengeindsamlinger sat i system, med salg af majblomsten som hovedindtrgtskilde.

Efter ti års arbejde i tuberkulosebekæmpelsen fik NKS en konkurrent - eller samarbejdspartner? - i NF, som blev stiftet af en bergensisk overlæge, der var primus motor bag en masse kommunalt arbejde. Foreningen blev en landsdækkende forening med lokale komiteer ligesom NKS. Dens medlemmer var hovedsagelig mænd, især læger. Dens program var en arbejdsdeling, hvor 
det offentlige i nært samarbejde med NF tog sig af driften af sanatorierne, plejehjemmene etc., mens kvinderne gjorde livet i sidstnævnte, hvor de uhelbredeligt syge tilbragte deres sidste tid, mere hyggeligt og hjemligt. Hovedkraften i de lokale afdelinger skulle også sættes ind på hjælp til det uformelle system. NF's krævede arbejdsdeling fulgte med andre ord de traditionelle kønsroller, og det tog NKS' nationale ledelse ilde op. Men faktisk var det netop således, Bergens afdeling af NKS havde arbejdet $\mathrm{i}$ årene forud. Dette forhold samt det, at lederen i Bergen var læge og god ven med stifteren af det lokale NF, gjorde, at samarbejdet dér blev meget frugtbart. Det gav til gengxld problemer mellem den lokale og den nationale ledelse af NKS, der på forhånd havde et noget anstrengt forhold til hinanden. Begge forkvinder var stærke, bramfrie og ofte uforsonlige skikkelser. Efterhånden faldt mistilliden mellem de to hovedbestyrelser dog bort, således at samarbejdet stort set gik gnidningsfrit. I Bergen kunne damerne i øvrigt også fint arbejde sammen med en socialdemokratisk arbejderkvindegruppe.

I de to sidste kapitler redegøres der for udviklingen inden for den offentlige og den frivillige omsorg og imellem disse instanser. Det viser sig, at det offentlige tog mere og mere over, og at tuberkulosebekæmpelsen blev en stor succes. Fastholdes skal dog også, at sygdommen både i Norge og rundt omkring i Europa faktisk havde toppet, før omsorgssystemerne rigtigt var blevet etablerede.

Den afsluttende konklusion relaterer bogens resultater til forskellige teorier om social kontrol, om frivillige foreningers samfundsmæssige rolle og om velfærdsstaten. Der kan bestemt ses ansatser til social kontrol, idet det offentlige og andre blandede sig i privatsfæren, en ting der i sig selv var uacceptabel i datidens opfattelse, men som imidlertid blev forsødet med økonomisk støtte, sengetxpper og spytflasker. Men det vigtigste resultat ligger for Ida Blom i fremhævelsen af husmoderens altdominerende rolle i bekæmpelsesarbejdet, fordi den internationale og nationale forskning normalt giver lægerne og deres pirquetprøver, gennemlysninger og vaccine hele xren for overvindelsen af tuberkulosen. Dødeligheden var allerede gået betragteligt tilbage, længe før disse tiltag blev almindelige. Her undervurderer forfatterinden $\mathrm{dog}$ betydningen af det arbejde, som netop lægerne siden midten af 1800-tallet havde lagt $i$ at oplyse om hygiejnen.

Med hensyn til teorier om velfærdsstatens opståen gjorde Ida Blom ikke eksplicit opmærksom på, at hun tilslutter sig den opfattelse, at fasen før dens opkomst bliver karakteriseret ved samtidigheden af frivillige organisationers arbejde og det offentliges socialhjælp samt ved det deraf følgende sam- og modspil imellem dem. I denne fase blev det klart, at en natvægterstat ikke var nok, idet frivillig hjælp i filantropiens regi ikke slog til. Det har Søren Kolstrup glimrende beskrevet for danske forhold i sin bog Velferdstatens rødder (1996). I Norge har man i debatten om velfærdsstatens oprindelse hæftet sig ved spørgsmålene om, hvorvidt frivillige organisationer var pionerer, og om i hvor høj grad deres hjælpearbejde var primært. At være pioner vil i denne sammenhæng sige at tage initiativ til en xndring af forholdene. Ida Blom viser, at NKS var pioner, idet det oprettede et arbejdshjem og et børnehjem, og de (frivillige) lægeforeninger ligeså, da det var dem, der påviste behovet for sanatorier og en tuberkuloslov. De frivillige foreninger var endvidere primære i den forstand, at kommunen først $\mathrm{i}$ anden omgang engagerede sig i flere af projekterne, idet de delfinancierede og i nogle tilfælde senere overtog dem.

Ida Blom er med sin bog i front i den internationale forskning, hvor humanister $\mathrm{i}$ de senere år har taget emner op fra sundhedssektoren generelt og epidemier specielt. Forskningen i pesten, den sorte død, ko- 
leraen, den blå angst, og tuberkulosen, den bvide pest, har givet adgang til det tavse flertals boliger; især gælder dette de to sidstnævnte, som hovedsageligt var fattigmands sygdomme. Kilderne hertil giver os et indtryk af de fattiges levevilkår. - Det er i øvrigt mærkeligt, at Ida Bloms påstand om, at de fattige blev hårdest ramt af tuberkulose, ikke underbygges med en tabel over tuberkulosedødes erhvervsfordeling, men kun med et skema over tætbefolkede boliger.

I det hele taget mangler bogen, der ellers er præget af uhyre grundigt og velovervejet arbejde, desværre det sidste lag fernis. Der er hyppige gentagelser - flere steder endog på samme side - og billedteksterne er ofte forbløffende (f.eks. s. 50: Under et billede af en gårdsplads med et stort træ i midten og nogle lave bygninger rundt om står der: Midlerne fra spedalsk-omsorgen pa St. Jørgens Hospital blev...omdisponeret til tuberkuloseformål. Er det et billede af St. Jørgens
Hospital? I så fald ses der ingen lighed med billedet på s. 48 , hvor netop dette hospital er udpeget. Og hvorfor er der egentlig de smukkeste haveroser på omslaget, når det nu er ville roser, der indgår i bogens titel?).

Ved den IV. Nordiske Kongres i Humanistisk Sundhedsforskning i april 1998 fremlagde Ida Blom, der nu arbejder med tuberkulosebekæmpelsen i Danmark, sine resultater. Det var her spændende at høre, at kvindeforeninger med tuberkulosebekæmpelse som formål her i landet glimrede ved deres fravær, og at tuberkuloseloven af 1905 manglede Norges to paragraffer om tvangsindlæggelse og anmeldelsespligt. Det sidste passer fint med anmelderens opfattelse af, at den danske regering normalt tog hensyn til befolkningens ønsker.

Gerda Bonderup

bistoriker, Historisk Institut A U 


\section{Det kønnede samfund}

\section{ANMELDELSE}

Red.: Ann-Dothe Christensen, Anne-Birthe Ravn og Iris Rittenhofer.

\section{Det kønnede samfund}

Aalborg Universitetsforlag, 1997 278 ,- kr.

\section{ANMELDT AF}

\section{LIS HøJGAARD}

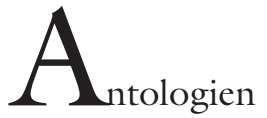

'Det kønnede samfund' er en vidtfavnende artikelsamling fra Freia - Center for Kvinde- og Kønsforskning ved Aalborg Universitet. Den er vidtfavnende i fagdiscipliner, i emner og i teoretiske tilgange, den rummer historiske, sociologiske og politologiske bidrag, overordnede teoretiske diskussioner og konkrete empiriske analyser. Men også indenfor det, der indledningsvist angives som antologiens fælles omdrejningspunkt, nemlig kvinde- og kønsforskningens videnskabsteoretiske grundlag og teoretisk- metodiske udgangspunkt (s.5) , favner den bredt - ja så bredt at diskussionen af køn i flere af bidragene opleves som lidt udvendig (det gælder især Bech-Jørgensens men også Sasoons bidrag). Den rummer, som jeg læser den, såvel dekonstruktivistiske, poststrukturalistiske, kulturteoretiske som ny-essentialistiske og mere pragmatiske analysetilgange, der kobler feministisk og politologisk teori. Og den rummer store forskelle i måden de enkelte bidrag griber den videnskabsteoretiske og metodologiske diskussion an på - fra explicit kritisk selvreflektion som udgangpunkt for den teoreti- 
ske diskussion hos f.eks. Ravn og Sassoon, over teorikritiske analyser f.eks. hos Rittenhofer, Siim og Christensen, til teoretiske præciseringer og fornyelse på baggrund af empiriske analyser hos Bak og Christensen. Endelig er der store forskelle i kvaliteten af bidragene, hvor nogle er velstrukturerede og gennemarbejdede og stramt argumenterede bidrag til standende forskningsdiskussioner, mens andre snarere er idé-skitser og på-vej-diskussioner.

Denne mangfoldighed er søgt disciplineret under tre hovedoverskrifter: 'Konstituering af køn', 'Hverdagsliv, familie og civilt samfund' og 'Medborgerskab og politisk kultur', og det lykkes rigtigt godt i første del, hvor alle tre artikler på hver deres måde diskuterer konstituering af køn, mens den store forskel på artiklerne $\mathrm{i}$ anden del kommer til udtryk i, at de tre begreber i overskriften så at sige dækker hver deres artikel. I tredie del indfanger overskriften fint to af de tre artikler, koblingen til den tredie ligger mere i den politologiske ramme, der er fælles for de tre artikler.

Som det nok fremgår, demonstrerer denne antologi, hvor differentieret og mangfoldig den kønsteoretiske diskussion kan være i dag - og det er spændende - men mangfoldighed og differentiering er ikke altid en dyd - bredde kan blive til spredning, og det lider denne antologi i nogen grad af. Dialogen mellem bidragene er sporadisk, ud over at enkelte af artiklerne refererer til enkelte andre, formidles diskussion ikke gennem artiklerne - heller ikke umiddelbart i læserens hoved, dertil er hovedparten af artiklerne for forskellige. Dette hænger dels sammen med genren generelt - antologier skal være stramt tematisk komponerede for at opfylde dette krav - dels med den specifikke udformning af genren, der er tale om her, hvor antologien i mindre grad er tematisk organiseret og snarere representerer status på et forskningsområde, hvor formålet i højere grad er at vise forskningsfeltets udstrækning. Det er nok en diskussion værd, om denne udformning af genren er god for kvindeforskningen idag - jeg tvivler. Jeg kunne godt frygte, at den målgruppe, den når, begrænser sig til andre kvindeforskere og kvindeforskningsmiljøer. Da mange af bidragene har en høj specialiseringsgrad inden for deres egne fagområder og rummer væsentlige indsigter at bidrage med også i fagspecifikke sammenhænge, ville det være kedeligt.

Men disse kritiske bemærkninger til helheden skal ikke dække over, at der er interessante, tankevækkende og informative bidrag i denne antologi. Jeg vil i det følgende kommentere de enkelte bidrag uden at gøre mig håb om at yde alle artikler eller alle aspekter af de enkelte artikler retfærdighed inden for de begrænsede rammer en anmeldelse sætter.

Antologien indledes med Iris Rittenhofer: Køn som diskurs, der i sin diskussion af kønsbegrebet trækker tæppet væk under både vores hverdagsopfattelser og videnskabelige begreber om køn, idet hun på bedste dekonstruktivistiske vis stiller spørgsmålstegn ved opfattelsen af køn som forskel, som bipolaritet og som komplementaritet. Hensigten er at komme selve kønsdualismetænkningen til livs, eller rettere fixere den som en specifik historisk forestilling, der er foranderlig - ikke en forudsætning for historien, ikke uden for historien men historisk konstrueret. Nu er vi jo mange, der, omend på forskellige måder, hælder til konstruktivistiske forståelser af køn - køn konstrueres i sociale processer, der bestandigt forandrer betydningen af køn. - Men Iris Rittenhofer går længere. Hendes ærinde er at historicere selve den bipolare difference, selve opfattelse af at der findes to og kun to køn. Hvis vi ikke dekonstruerer denne grundlæggende forskelstænkning, er vi uafvidende, også i kvindeforskningen, med til at reproducere netop den kulturelle forestilling om køn, som er de kønnede tilskrivninger/konstruktioners grundlag. Med andre ord, Iris Rittenhofer plæderer for, at vi, skal undersøge 'processer af kønsliggørelse' (s21) fremfor at analysere køns- 
forhold, og som historiker betyder det dekonstruktion af tekster - en tilgang hun demonstrerer med flere konkrete tekstanalytiske eksempler. Jeg har stor sympati for bestræbelser af denne karakter og er nysgerrig efter af finde ud af, hvor en forskningsstrategi, der bygger på analyser af processer af kønsliggørelse, kan føre os hen.

Anna-Birthe Ravn: 'Køn $i$ historisk forandring' giver et konkret historisk eksempel på indstiftelsen af kønsdualismen - på arbejdsmarkedet - i sin analyse af den danske arbejderbeskyttelseslovning fra århundredeskiftet. Hun viser, hvordan debatten om loven kan ses som brydninger mellem to holdninger til køn og arbejde. Den ene betoner forskellene mellem kønnene, i sin fremhævelse af manden som normen og kvinderne som afvigere, fordi de defineres primært som mødre - mens den anden betoner lighederne - kvinder og mænd som arbejdere - hvor kvinderne i perioder også er mødre. I Danmark var det den sidste holdning, der sejrede lovgivningsmæssigt, men Anna-Birthe Ravns påstand er, at selve debatten bidrog til at skabe den dominerende diskurs, der indsætter manden som normalarbejderen og kvinden som moder, der har præget kønsopfattelsen på arbejdsmarkedet siden, og som ses som en magtfuld faktor bag udformningen af det nuværende kønsopdelte arbejdsmarked. Analysen af beskyttelseslovgivningsforløbet er dog ikke artiklens hovedsigte. Anna-Birthe Ravn sætter sig for at diskutere sine forskningsresultater $\mathrm{i}$ lyset af forskellige analytiske tilgange - en materialistisk overfor en diskursanalytisk tilgang - et prisværdigt selvrefleksivt projekt, som forskere alt for sjældent giver sig i kast med. I denne proces trækkes på en række historieteoretiske diskussioner, som kan være svære at følge for en ikke-historiker, men resultatet af diskussionen i form af nuancering af forståelsen og fortolkningen af den danske særlovgivningsprocess og dens samfundsmæssige konsekvenser er spændende.

En ganske anden tilgang og et andet kønsbegreb kommer til udtryk i Susanne Thorbeks: 'Ud over ligestilling. Teorier og myter. Mens Iris Rittenhofer viser, hvordan kønsdualismen indstiftes gennem naturaliseringen af mandligt og kvindeligt gennem kroppen, argumenterer Susanne Thorbæk for at tage kvindekroppen - følelserne, lysten, sexualiteten, de tavshedsbelagte kropsbundne dimensioner af kvindelivet - som udgangspunkt for en kvindepolitisk og kvindeforskningspolitisk strategi. Fremfor at fokusere på ligheder, som inden for den sociale kontrakts univers viser sig som lighed på mandlige præmisser og dermed som underordning, mener Susanne Thorbæk, at vi skal tage forskellen - og hvad har vi her andet, ikke mindst når perspektivet er globalt, end de kropslige forskelle - som politisk og forskningsmæssigt afsæt, og hun henter støtte for sin argumentation hos så forskellige teoretikere som Patemann, Irigaray og Spivak. Jeg vil provokatorisk kalde dette synssæt for ny-essentialistisk. Ny- fordi Susanne Thorbæk åbner for et konstruktivistisk perspektiv, som ellers ligger essentialismen fjernt, men som ganske vist ikke udfoldes - og essentialistisk, fordi det relancerer et biologisk funderet kønsforskelsbegreb helt uden at reflektere det spørgsmål om patriarkatets/kvindeundertrykkelsens fingeraftryk på vore kroppe, lyster og følelsesliv, som poststruktualisterne og mange andre med dem stiller og har stillet til i alt fald både Pateman og Irigaray. Hvordan kan kroppen være en priviligeret erfaringsbase for bekæmpelse af underordning, når den samtidig er et produkt af denne underordning? Jeg kan godt være enig $i$ vigtigheden af at analysere kroppens betydning, men nok mere i Iris’s 'kønsliggørelses-forståelse' end indenfor rammerne af universelle manifestationer af kvindelig kropslighed.

Susanne Thorbæks bidrag står, med sit universalistiske perspektiv, i modsætning til en række bidrag $\mathrm{i}$ antologien, som argumenterer for nødvendigheden af kontextualisering for teoretisk fornyelse som f.eks. 
Bithe Siim og Ann-Dorthe Christensen. Birthe Siim argumenterer i artiklen 'Politisk medborgerskab og feministiske forståelser' for betydningen af den specifikt politiske kontekst, det vil sige for de politiske institutioners, kulturers og diskursers betydning for den integration af kvinder i politik, som er sket i de nordiske lande fra 70'erne frem til idag. Diskussionen løsner forklaringsrelationen mellem kvinders erhvervsdeltagelse og deres familietilknytning fra deres øgede politiske deltagelse og repræsentation på baggrund af de nordiske medborgerundersøgelsers resultater - men jeg savner en præcisering af de teoretiske implikationer af denne forståelse af den politiske konteksts betydning. Den udfoldes, så vidt jeg kan læse, hverken i Birthe Siims ellers interessante diskussion af udviklingen i de feministiske forståelser af kvinders politiske integration eller i hendes diskussion af udviklingens betydning for kvinders medborgerskab.

I Ann-Dorthe Christensen: 'De politisk kulturelle betydninger af køn' skærpes kontekstualiserings bestræbelserne yderligere, idet hun inddrager generationskonteksten i sin analyse af udviklingen i kønnenes politiske deltagelse og politiske holdninger og viser forskellene mellem generationerne $\mathrm{i}$ begge køns mobiliserings- og holdningsmønstre. Det er en spændende og tankevækkende analyse, både fordi de politiskkulturelle betydninger her konkretiseres, men også fordi projektet så at sige viser ud over sig selv, i og med, at det Ann-Dorthe Christensen sætter sig for efter min mening ikke rigtigt lykkes, og dermed understreges artiklens pointe om behovet for teoretisk ny-udvikling indenfor den nordiske kvindeforskningsdebat yderligere. For AnnDorthe Christensen er det i skæringspunktet mellem det sociale og det politiske, at forståelsen af den moderne politiske udvikling skal hentes, og da det sociale dækker de sociale relationer i hverdagslivet, repræsenterer den generationsopdeling, der anvendes i analysen, da også 4 forskellige sæt af relationer mellem kønnene i arbejdsliv, familieliv og i kønsrollemøntrene. Men den overensstemmelse, der på det generelle plan kan konstateres mellem udviklingen i kønsrelationerne og i den politiske deltagelse - mere lighed begge steder - holder ikke for det der kaldes velfærdsgenerationens mobilitetsbærende lag, hvor uligheden er større end i generationen som helhed, og den holder slet ikke for 80'er generationen, hvor den større sociale lighed godt nok modsvares af øget lighed i politisk deltagelse, men samtidig viser en markant tendens til polarisering $\mathrm{i}$ de politiske holdninger. Ann-Dorthe kobler ikke explicit tilbage til sit analytiske udgangspunkt i samspillet mellem det sociale og politiske - men understreger behovet for nuancering af tilgangen f.eks. gennem inddragelse af klasserelationer. For mig at se peger analysen enten på, at præmissen om kønsrelationerne som central generationsmarkør ikke gælder så generelt, som her antaget - det støtter måske Birthe Siims antagelser om øget autonomi på det politiske felt - eller at både den præmis og tesen om samspillet mellem det sociale og det politiske skal nuanceres. Analysen kalder på yderligere præcisering af, hvad vi skal forstå ved politisk-kulturel betydning.

At ovenstående - hverdaglivsanalysen ikke er nogen helt enkel opgave kan man blive overbevidst om ved at lase Birthe Bech-Jorgensen: 'Symbolsk orden og hverdagskultur', som er et forsøg på at opstille et begrebsapparat for analyser af hverdaglivet. Det centrale begreb er 'selvfølgelighedens symbolske orden', der defineres som et komplekst væv af betydninger, der gør det muligt at fortolke sin omverden, orientere sig og få hverdagen til at hænge meningsfyldt sammen (s.122). Det er således et begreb, der ligger tæt på kulturbegrebet, som det er udformet i megen antrolpologisk litteratur, blot med den afgørende forskel at det ikke dækker hele det sociale livs væv af betydninger, men kun nogle - og der er ikke kun een symbolsk orden af selvfølgelig- 
heder, men mange. Selvfølgelighedens symbolske orden er desuden karakteriseret ved både at være en grundlæggende betingelse for hverdagslivet og en grundlæggende struktur og bestemmes yderligere i relation til hverdagskulturbegrebet, der er lokalt, som tids-og rumsligt en mere omfattende kulturel betingelse end en hverdagskultur. Jeg er overbevidst om, at Birthe Bech-Jørgensen har fat i de centrale dimensioner af hverdaglivet med dette begreb, fordi det indfanger hele det upåagtede, umærkelige lag af handlinger og betydninger, der gør det daglige liv muligt. Men ovenstående er efter min bedste overbevisning ikke en fremkommelig, brugbar definition, og den er karakteristisk i sine uklare konturer for det begrebsapparat, der opstilles i artiklen. Jeg tror et hovedproblem er, at begreberne ikke defineres efter deres indhold, men efter deres form - deres tidslige- rumlige udstrækning. Det bliver derfor aldrig klart hvilke sociale fænomener, der hører med, og hvilke der ikke hører med. F.eks. hører så forskellige fænomener som leg, glæde, længsler og kærlighed ikke med i selfølgelighedens symbolske orden, men det forlyder ikke om andre følelser, andre aktiviteter er indkluderet. Begrebsapparater er opbygget som et komplekst abstrakt kinesisk xskesystem, hvis analytiske potentialer enten ikke demonstreres i artiklen, eller når det gøres, skaber mere uklarhed end klarhed - som når den måde, efterkommerne af polske roearbejdere håndterer deres arbejdsløshed på ved at opretholde lønarbejderlivets hverdagsrutiner, både skal eksemplificere en lokal overlevelseskultur (s.120) og en symbolsk orden af selfølgeligheder og et betydningsunivers (s. 130). Selv om alle tre ting godt kan være rigtige, synes anstrengelserne ikke at stå mål med udbyttet i form af øget forståelse. Hovedparten af de empiriske eksempler, der indgår i artiklen, har snarere den funktion at vise, hvordan begreberne blev skabt, end hvordan de kan give os en ny og anderledes adgang til at forstå hverdaglivet, og det er ærgerligt.
Maren Bak har skrevet en spændende og perspektivrig artikel om enlige mødres opfattelser og brug af tid : 'Kvinders tid. Om enlige modres hverdagliv og tid'. Med udgangspunkt i en diskussion af tidsbegrebet og den cykliske og liniære tids koblinger til køn føres vi ind i en række kvinders beskrivelser af deres brug og opfattelser at tiden. Opdelingen i to slags tid er tydelig og det, der fascinerer, er kvindernes beskrivelser af de kvaliteter, de lægger ind i den cykliske tid, deres nydelse af den ustrukturerede tid. Maren Baks analyse demonstrerer, at den cykliske tid er kønnet, i og med at den er stuktureret af det samtidige ansvar for forsørgelse og omsorg. Det samme kunne man vel i og for sig også sige om den liniære tid jvf. de begrænsninger flere af kvinderne søger at lægge på lønarbejdstiden. Men jeg synes, at analyserne derudover viser, at værdierne i de fleste kvinders liv er knyttet til begge tidsstrukturer. Kvinder ønsker også den liniære tids strukturering af deres liv. For de fleste af undersøgelsens kvinder synes det at være koblingen af de to tidsformer, der har værdi, også selv om de synes, at den liniære tid fylder for meget. Men som Maren Bak påpeger, er det mest interessante, de krav om autonomi i deres beslutninger om tid og om rådighed over egen tid, som kvinderne stiller - de rummer modstand mod opdelingen af tiden og mod lønarbejdets dominans.

Antologien rummer også to engelsksprogede bidrag. Det ene er Anne Showstack Sassoon: 'Gender Gramsci, and the Debate about Civil Society', som er en genlæsning af Gramsci's begreb om det civile samfund. Det er en spændende, men meget komprimeret og kompleks diskussion, som munder ud i en kort diskussion af de, først og fremmest, metodologiske indsigter, som kvinde- og kønsforskningen kan hente her. Den anden er Pauline Stoltz: 'Look! Women - on Black Women and the paradoks of Visibility', som diskuterer mulighederne for at opretholde den demokratiske universalitets fordring når selve synliggørelsen af grup- 
per, f.eks. kvinder eller sorte samtidigt bliver ekskluderende og diskriminerende. Hun eksemplificerer dette, gennem den måde sorte og indvandere behandles på $\mathrm{i}$ europæisk lovgivning, og gennem de vanskeligheder et politisk samarbejde mellem sorte og hvide kvinder står overfor.

Antologien viser, at der er bevægelse og grøde i kvinde- kønsforskningen, men den præsenterer samtidigt det dilemma for en udbredelse og integration af dens resulta- ter, at den på den ene side forfægter kvinde- og kønsforskningen som et samlet forskningfelt, samtidigt med at den demonstrerer omfattende differentiering teoretiskmetodisk og tematisk - Jeg tror, vejen ud af det dilemma er strammere tematisk komponerede artikelsamlinger, der også vil appelere til fagspecifikke sammenhænge.

Lis Højgaard $K U$ 


\section{Mod et mindre \\ kønsopdelt
arbejdsmarked? \\ kønsopdelt
arbejdsmarked?}

\section{ANMELDELSE}

\section{Vibeke Kold}

En køn historie om elektronikarbejde.

Kønsarbejdsdeling og ligestilling på det ikke-faglærte industrielle arbejdsmarked 1945-1993

Selskabet til Forskning i

Arbejderbevægelsens Historie

Skriftserie nr. 40, 1997

(kan købes ved henvendelse til SFAH, Nørrebrogade 66D, 2200 København N Tlf. 35361522 ).

325 s. excl.bilag., 175,- kr.

\section{ANMELDT AF \\ Marianne RostgaARD}

$\bigcup_{\text {om titlen måske }}$

allerede signalerer, er der tale om en afhandling, nærmere bestemt en ph.d.-afhandling, udarbejdet i perioden 1992-95 på Center for Kvinde- og Kønsforskning og Center for Arbejderkulturstudier på Københavns Universitet. Stipendiet var delvist finansieret af KAD (Kvindeligt Arbejderforbund i Danmark) og LO. Det er værd at nævne, fordi det er første gang KAD og fagbevægelsen har støttet et ph.d.-studie.

De to hovedafsnit $i$ afhandlingen behandler ændringer i kønsarbejdsdelingen og udviklingen i ligestillingen på den københavnske elektronikvirksomhed Radiometer i perioden 1945 til 1993. Såvel ændringer i kønsarbejdsdelingen som ændringer i ligestillingen gennemgås detaljeret, afdeling for afdeling, og opdelt på tre tidsperioder: 1945 til slutningen af 1950'erne, slutningen af 1950'erne til midt i 1970'erne og midten af 1970'erne til begyndelsen af 1990'erne. Periodiseringen er foretaget ud fra ændringer i kønsarbejdsdelingen, fra mandedominans i den første periode, til en midterperiode kendetegnet ved en skarp kønsarbejdsdeling og en sidste periode ken- 
detegnet ved tendenser til opblødning i kønsarbejdsdelingen.

Vibeke Kold har valgt et case-studie af ændringer på en enkelt virksomhed, med de problemer og muligheder det giver. Det særlige ved Vibeke Kolds afhandling er dog i højere grad kombinationen af et historisk perspektiv og en aktuel analyse. Det har også givet anledning til nogle utraditionelle valg hvad angår kombinationen af metoder og kildemateriale. Til forskel fra flertallet af historiske afhandlinger, har Vibeke Kold valgt ikke kun at bruge materiale fra diverse arkiver, men har også brugt interviews. $\mathrm{Og}$ til forskel fra de sidste 10-20 års analyser af kønsarbejdsdeling og ligestilling i et nutidsperspektiv er interviews blevet suppleret og sammenholdt med skriftligt materiale af forskellig karakter; internt statistisk materiale, personaleblade, mødereferater m.v. Selvom afhandlingen i hele sin opbygning og måde at behandle spørgsmålet på er lagt historisk an, er der tale om en afhandling, der har hentet stor inspiration, hvad angår såvel teori som metoder, fra samfundsvidenskaberne. Ser vi på, hvilke perioder der fylder mest i analysen, er det klart perioden fra midten af 1970'erne til begyndelsen af 1990'erne, og den periode, der behandles mest indgående, er ofte den allernyeste, måske også fordi det er her, de mest spændende ting sker. Hvad kommer der så ud af at anlægge en historisk synsvinkel, når afhandlingen, i den tidsperiode der behandles mest indgående og i teori og metode, på en del områder ligger relativt tæt op ad lignende rapporter udarbejdet af samfundsforskere?

Jeg mener, at en af de mest spændende konklusioner på Vibeke Kolds undersøgelse er, at der i 1990'erne ses tendenser til en øget kønsintegration og en større ligestilling mellem mænd og kvinder. Kønsintegration $\mathrm{i}$ form af at mænd og kvinder $\mathrm{i}$ 1990'erne i større grad end tidligere udfører samme arbejdsfunktioner. Øget ligestilling målt i.f.t. løn, hvor ikke-faglærte mænd og kvinder fra 1995 har fået samme timeløn på Radiometer, og målt i.f.t. uddannelse, hvor der igen ses et skift i 1990'erne, hvor de ikke-faglærte kvinder i dag i langt højere grad end tidligere har lyst til at komme på kurser, og kommer det. Uden en historisk vinkel, hvor der sammenlignes med perioder før, med en skarp kønsarbejdsling og en tydelig uligestilling, ville man måske ikke få øje på, at der er tale om et brud i 1990'erne, men måske i stedet have hæftet sig ved alle de områder, hvor der stadig er tale om en uligestilling. For selvfølgelig er der også stadig mange uligheder, og afdelinger og fagområder hvor der er en skarp kønsarbejdsdeling.

Holder resultaterne - at vi er på vej mod øget kønsintegration på arbejdsmarkedet stik, er der imidlertid tale om en historisk begivenhed. Før vi begynder at tale om et historisk brud - og det er ikke ment ironisk - må det dog være på sin plads, at diskutere Vibeke Kolds konklusioner nærmere, og indskyde, at det ikke er Vibeke Kold, men anmelderen der taler om en historisk begivenhed. Vibeke Kold tager selv en række forbehold og generaliserer bestemt ikke resultaterne udover, hvad de kan bære.

Det der sammenlignes i Vibeke Kolds analyse, er, hvad der umiddelbart må være mest relevant, ikke-faglærte mænd og kvinder (SID'ere og KAD'ere). På den anden side fremgår det også klart af Vibeke Kolds undersøgelse, at de faglærte på Radiometer (med en enkelt undtagelse) alle er mænd, og det samme mønster gentages, hvis vi ser på arbejdsledere m.v. Samtidig konkluderes det $\mathrm{i}$ undersøgelsen, at hvor køn tidligere har trukket en skarp skillelinje mellem arbejdsfunktioner, er den store skillelinje i dag fag, d.v.s. spørgsmålet om faglært eller ikke-faglært. Hvis sammenligningen derfor i stedet går på mænd (faglærte samt ikkefaglærte) $\mathrm{i}$ industrien overfor kvinder $\mathrm{i}$ industrien (der stor set altid er ikke-faglærte), så er der stadig tale om kønsarbejdsdeling og store uligheder i arbejds- og lønvilkår.

Med dette forbehold in mente er der dog mindst to grunde til at argumentere 
for, at der er tale om et brud, og at der er nye tendenser på vej i 1990'ernes arbejdsmarked. Vibeke Kolds analyser viser, at der systematisk er tale om en generationsforskel, både når det gxlder holdninger til kvinders og mænds arbejde, og når det gælder handling, eksempelvis i spørgsmålet om uddannelse. En af de interessante iagttagelser er, at særartsopfattelser trives langt bedre blandt de xldre folk på Radiometer hos mændene såvelsom kvinderne - mens en ensartsopfattelse, d.v.s. at mænd og kvinder i princippet er ens og kan det samme, gør sig gxldende blandt de yngre generationer, mænd såvelsom kvinder. En anden grund til at man ud fra Vibeke Kolds analyse kan argumentere for, at der formentlig er tale om et brud, er, at kønsintegrationen er knyttet til de nye former for arbejdsorganisation. Jobrotation og jobudvikling (hvor den enkelte udfører flere og bredere arbejdsfunktioner) betyder, at den skarpe kønsarbejdsdeling fra "midterperioden" tendentielt går i opløsning. Og da jobrotation og jobudvikling er knyttet til de nye produktionskoncepter og krav til produktkvalitet, og dermed til virksomhedernes konkurrenceevne, er det stærke kræfter, der trækker i retning af kønsintegration. Et tredje argument for, at der er tale om et brud i 1990'erne, er, at lovgivningen på ligestillingsområdet er begyndt at virke. Ligelønslovgivningen, og det politiske pres som forbund og lokale klubber har udøvet, begynder åbenbart at have effekt. Endelig er der tale om, at et generelt holdningsskift siden midten af 1970'erne har virket som forandrende kraft, og selvfølgelig også har haft indflydelse på den førte politik.

I forlængelse af konklusionen stilles spørgsmålet, "Hvad kan undersøgelsen bruges til?" Der peges her dels på nogle mere generelle mønstre og faktorer, der har fremmet ligestilling, hvoraf nogle er nævnt ovenfor, og andre der ikke har. Herudover diskuteres og problematiseres ligestillingsbegrebet. Som Vibeke Kolds undersøgelse viser, er mænd og kvinder ikke nødvendig- vis enige om, hvad et godt arbejde og hvad et godt arbejdsliv er. Det giver nogle (velkendte) dilemmaer, når der diskuteres ligestilling. Ligestilling på hvis præmisser? Eller er ligestilling, at åbne op for et mere individuelt valg og give mulighed for at mænd og kvinder f.eks. kan indrette sig forskelligt med hensyn til arbejdstid?

Jeg synes Vibeke Kolds analyser er spændende og noget af det mest interessante, der er skrevet om det kønsopdelte arbejdsmarked i de sidste par år. Det er ikke alle de spørgsmål der stilles, der svares på, men der lægges i alle tilfælde op til en kvalificeret diskussion. Værket burde derfor være let at anbefale, til alle der interesserer sig for køn og arbejdsmarked. Det er dog nok kun akademikere og andre meget interesserede, der vil have mod på at læse sig igennem alle de detaljerede analyser. Det er her, der fremlægges dokumentation, men på den anden side er det ikke lige spændende at læse sig igennem udviklingen på de udvalgte områder, i de tre forskellige perioder i de forskellige afdelinger på Radiometer, med mindre man altså har blik for nuancer og brænder for sagen. At det er en ph.d.-afhandling, betyder også at der er nogle afsnit, der er pligtstof $i$ en sådan afhandling, men som vel heller ikke altid har lige stor interesse for læserne. Det er lidt synd, at der i et ph.d.-forløb ikke er tid til, at man bagefter kan bearbejde resultaterne til udgivelser, der også ville kunne læses af en lidt bredere kreds. På den anden side er det godt, at afhandlingen er blevet udgivet og gjort tilgængelig, selvom det er på simplest mulige vis, tekst uden billeder og uden andre lay-out mæssige raffinementer end dem der også kunne laves i skrivemaskinernes tid. Mig generer denne halvfjerdserxstetik ikke voldsomt og for så vidt passer tekst og lay-out m.v. sammen, begge lægger op til, at det er en bog for den professionelt interesserede og ikke for en bredere kreds.

Marianne Rostgaard $\mathrm{AaU}$ 


\section{Enlige mødres livsvilkår}

\section{ANMELDELSE}

Jane Lewis

\section{Lone Mothers in European Welfare} Regimes - Shifting Policy Logics

Jessica Kingsly Publishers, London 1998 224 s., 150,- kr.

Maren Bak

\section{Enemorfamilien}

Forlaget Sociologi, København 1998 256 s., 198,- kr.

\section{ANMELDT AF}

\section{LARS JALMERT}

ag blev ombedd att anmäla två böcker om ensamma mammor och deras livsvillkor. Först tyckte jag att det kanske skulle vara extra spännande med en man som anmälde böcker av kvinnor om just ensamma mammor. Vid närmare eftertanke har jag svårt att se att detta skulle ha någon egentlig betydelse. Samtliga författare är forskare och arbetar inom fältet familjerelationer och detta är också mina utgångspunkter.

Jane Lewis har varit redaktör för "Lone Mothers in European Welfare Regimes" med den viktiga underrubriken Shifting Policy Logics. I den skriver elva forskare om strukturella faktorer och förändringar som påverkar ensamma mammors liv. Utgående ifrån sociologiska, socialpolitiska och statsvetenskapliga perspektiv redovisar de sju olika välfärdsstaters syn på ensamma mammor. Boken är, naturligtvis, en guldgruva för den som vill få kunskap om ett enskilt land men också för möjligheterna till jämförelser.

Självfallet utgår författarna från sina teoretiska ramar och discipliner. Själv skulle jag dock önskat att åtminstone någon av dem 
tagit in ett mer psykologiskt, individualistiskt perspektiv. I Sverige har vi nämligen under 90-talet fătt se en återgång till essentialistiska, biologistiska och gammalpsykologiska resonemang kring könen. Det känns som om 70-talets "myt om den goda modern" har dammats av och faktiskt också ligger bakom och påverkar synen på den ensamma mamman - och därmed är den en viktig psykologisk kraft som jag gärna sett diskuterad.

Eftersom bokens fokus är på de ensamma mammorna skall, naturligtvis, inte fäderna ha något större utrymme. Det har de inte heller men diskuteras i verklighetens inte alltför smickrande ljus. Så konstaterar författarna torrt att fädernas ekonomiska bidrag till ensamma-mamman-familjen är den mindre delen av inkomsterna.

En annan infallsvinkel presenteras av Maren Bak i "Enemorfamilien”, som för övrigt är en förkortad version av hennes doktorsavhandling från 1996.

Maren Bak har genomfört en undersökning av hur ensamma-mamman-familjen konstruerar och lever sin vardag - och det har vi hittills vetat relativt litet om. Bak har studerat danska familjer och bilderna kan möjligen generaliseras till Norden.

Bak finner att kvinnorna i stort agerar efter en av två familjestrategier. Den traditionella familjestrategin innebär att kvinnan även efter skilsmässan agerar och lever för att åter få leva i den traditionella kärnfamiljen. Litet syrligt benämner Bak också strategin för "väntan på prinsen". I denna strategi lever ensamma-mamman-familjen i ett "förtätat familjerum" vilket innebär att allt centreras kring modern och barnen med en snäv krets av människor runt dem. Detta le- der till ett stort beroende mellan mor och barn. Något som kan ses som både gott och ont - men barnen kan komma att uppleva att de inte lever ett fullvärdigt liv eftersom det saknas en far i familjen.

Den andra strategin är den självbärande, vilken innebär att kvinnan uppfattar den nya familjen, ensamma-mamman-familjen, som fullvärdig. I denna strategi lever familjen i ett utvidgat familjerum där vänner, släktingar, tidigare partner och andra människor har relationer både till mamman och till barnen. Bak drar en mycket viktig slutsats:

"I modsætning til en stor del af forskningen om børn efter skilsmisse hævder jeg, at moderens familiestrategi og adgangen til et udvidet eller fortættet familierum spiller en større rolle for børnenes muligheder for at konstruere deres barndom end den måde, forældreskabet er etableret på efter skilsmissen."

Bak redovisar också den stora betydelse som arbetet har för mamman - för att ingå i ett samhälleligt sammanhang, för försörjningen och för självrespekten. I detta sammanhang varnar hon också för de allvarliga konsekvenser en hög arbetslöshet har för speciellt ensamma-mamman-familjerna.

Baks bok ger en spännande redovisning av vardagslivet. Tillsammans med en utmärkt genomgång av tidigare forskning ger hon oss ett stort bidrag till kunskapen om enförälderfamiljen.

Lars Jalmert, docent Pedagogiska institutionen Stockholms Universitet 


\section{Kinas et-barns politik}

\section{ANMELDELSE}

\section{Cecilia Nathansen Milwertz}

\section{Accepting Population Control-Urban Chinese Women and the One-Child Family Policy}

Curzon Press, 1997, Great Britain 249 s., 130,- kr. plus leveringsomkostninger på $40 \mathrm{kr}$.
ANMELDT AF
QI WANG

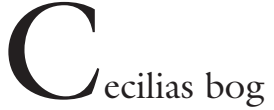

handler om Kinas et-barns politik, som siden 1979 er blevet gennemført på landsplan af Kinas ledelse. Bogen sætter fokus på byområder, hvor et-barns politikken er blevet en stor succes og belyser dermed, hvordan kvinderne i de kinesiske byer forholder sig til ledelsens krav om, at et ægtepar kun må få et barn.

Bogen baserer sig på spørgeskema-undersøgelser og "in-depth" interviews, som forfatteren har foretaget i to udvalgte storbyer. Den ene er Kinas hovedstad Beijing, og den anden er den berømte tung-industri by i det nordøstlige Kina, Shenyang. Bogen tager udgangspunkt $i$, at der er en klar $u^{-}$ overensstemmelse mellem det antal børn, som kvinderne ønsker sig og det antal børn, som kvinderne har tilladelse til at føde. Forfatteren argumenterer med, at selvom de fleste kvinder blandt de undersøgte har givet udtryk for, at de foretrækker at have mere end et barn, kan uoverensstemmelsen mellem kvindernes ønsker og ledelsens krav om et barn per familie alligevel tolkes som et tegn på kvindernes anerkendelse af et-barns politikken.

Bogen viser, at kvinderne i de kinesiske 
byer stort set har en positiv holdning til etbarns politikken, trods anvendelse af tvang $\mathrm{i}$ befolkningskontrolprogrammet. De er enige med ideologien bag et-barns politikken, som anser overbefolkningen for at være en trussel mod den økomoniske udvikling, de støtter ledelsens indstilling til, at befolkningstallet skal nedsættes til fordel for økonomisk vækst, og de mener iøvrigt, at Kinas indførelse af et-barns politik er nødvendig.

Bogen beskriver detaljeret, hvordan etbarns kampagnen foregår på arbejdspladserne og i beboelseskvartererne, og hvordan kontrollen omkring fødselstal i Kina kører sammen med velfærds service for at sikre både børnebegrænsningen og mødrenes sundhed. Herunder giver bogen en spændende analyse af, hvordan kinesiske kvinder i deres daglige liv tackler kløften mellem et-barns politikken og de traditionelle forventninger til det at have flere børn. Bogen viser, at ønsket om flere børn ikke forsvinder på grund af indførelsen af et-barns politikken, men bliver "transcended". Et-barns-mødre investerer nemlig meget i barnet. De stræber efter at udvikle et "perfekt" barn, og dermed opfylder kvinderne også deres rolle som den gode hustru og mor.

Et-barns politikken som emne er ikke noget nyt i sig selv, idet der allerede findes hundredvis værker om det. Cecilia Milwertzs fremstilling er fremragende på den måde, at hun drager emnet ind i et helt nyt perspektiv. I akademiske kredse verden over har man længe udforsket et-barns politikken ud fra socioøkonomiske, politiske og demografiske synsvinkler. Selvom man har konstateret, at den mest afgørende faktor i Kinas faldende fødselsrate er et-barns politikken, og at der er en synlig uoverensstemmelse mellem det antal af børn, som kvinderne ønsker sig og det antal af børn som de må føde, har forskerne indtil nu kun fokuseret på konsekvenserne af et-barns politikken i implementeringsfasen, hvor en række problemer er opstået. F.eks. mishandling og vold $\mathrm{i}$ form af tvangsabort og sterilise- ring, økonomisk straf af uplanlagte fødsler, destruktion af folks huse som en form for straf, mishandling af kvinder som har født et pigebarn, drab af pige-spædbørn udført af forældrene, drab af spædbørn ved den anden eller tredie fødsel udført af hospitalspersonalet osv.

Bogen adskiller sig fra de tidligere fremstillinger, idet den retter fokus mod folks oplevelse af og reaktion på et-barns politikken. Den kaster dermed lys på de mange spørgsmål vedrørende et-barns politikken udenfor "policy implementations" fasen, nemlig hvordan almindelige folk har det med et-barns politikken, og hvordan etbarns mødre i Kina reagerer i forhold til det voldsomme brud med traditionen og omstiller sig til det. I den sammenhæng bruger forfatteren hverdagslivsteori som tilgang og bringer folks adfærd, kvinders kulturelle og individuelle strategier, et-barns familiens daglige liv osv. ind i billedet. Her drejer det sig ikke længere kun om statistik og de overordenende strukturer, men også om de almindelige mennesker bag statistikken og om konsekvenserne af et-barns politikken, som folk har oplevet den i deres hverdagsliv.

Cecilia Milwertzs fremstilling af et-barns politikken er glimrende for så vidt, at forfatteren ikke lader sig binde af menneskerettighedsproblematikken. Menneskerettigheder og kvinders selvbestemmelse er blandt de grundlæggende værdier i vestlig kultur. Derfor er Kinas et-barns politik blevet kritiseret voldsomt for at have overtrådt kvinders ret til selv at bestemme, hvor mange børn de vil føde, trods landets succes med at bremse befolkningstilvæksten. Og netop menneskerettighedskritikken har i et vist omfang forhindret forskerne $i$ at kigge nærmere på folks oplevelser af befolkningskontrollen. Bogen bryder simpelthen med “menneskerettighedsoverfladen". Forfatteren konstaterer, at et flertal blandt de kvinder, som hun har interviewet, ikke deler hendes synspunkt angående menneskerettigheder. Derfor dykker forfatteren længere 
ned i det kulturelle undervand og leder der efter forklaringer på, hvorfor kvinderne i Kina overhovedet kan acceptere den politik, som vestlige kvinder under ingen omstændigheder vil acceptere.

Bogen har derfor også en fin iagttagelse af kinesisk kultur og tænkemåde. Forfatteren peger på, at mange kinesiske kvinder ikke opfatter et-barns politikken som en krænkelse af deres selvbestemmelse. Ifølge traditionen vil familien alligevel gå ind og bestemme, hvor mange børn en kvinde skal føde. Derfor synes mange kvinder, især de veluddannede, at befolkningskontrol er godt for kvinderne, fordi den virkeliggør kvindernes drøm om at føde færre børn. Forfatteren fremhæver også en række kulturelle egenskaber, som er væsentlig anderledes end vores, og som gør, at kinesere har en helt anden reaktion over for et-barns politikken, end vi forestiller os. Der er f.eks. et vigtigt begreb i kinesiske kultur, nemlig gensidighed. Gensidighed går ud på, at man bør gøre gengæld overfor andre, hvis man har făet noget af andre, og dette gxlder både menneskelige relationer og relationen mellem staten/det offentlige og individet. I denne sammenhæng er det ikke helt utænkeligt for kineserne, at skulle ofre deres "ret" til at få flere børn. Bogen viser, at det er mere eller mindre oplagt for kineserne, at staten og arbejdspladser giver tryghed og velfærd, og at hvert individ bør give noget til gengæld til staten og arbejdspladserne. Øvrigt viser bogen også, hvordan gensidighed styrer relationen mellem generationer på den måde, at et-barns mødre ofrer alt for at udvikle et "perfekt" barn, således at barnet kan gøre gengxld, når det vokser op.

Det er mit indtryk, at bogen har en bred referenceramme, og at forfatteren har et klart overblik over de vigtigste værker inden for området. I bogen refererer forfatteren til videnskabelige fremstillinger i tre brede felter, nemlig Kinas befolkningskontrol, forholdet omkring kvinder i Kina, og kinesisk kultur og kulturelle normer. Jeg synes, at det er en ganske flot kombination, fordi den dækker bogens tema fuldstændigt. Desuden viser forfatteren stort kendskab til de forskellige kinesiske kilder og evner at bruge dem i den rigtige sammenhæng. Det er ret imponerende, at forfatteren har fået så mange kinesiske bøger og artikler om kvindestudier og fødselskontrol med i sin litteraturliste. Jeg finder, at oversættelsen af det kinesiske stof i teksten generelt er flot. Der er steder, hvor forfatteren kommer med gode uddybninger af kinesiske begreber, som f.eks. det kinesiske ord for "frivillig".

Som et videnskabeligt værk er bogen bestemt ikke tør og kedelig. Dette gælder ikke blot bogens indhold, men også dens layout og illustrationer. Bogens forside viser feks. et billede af et ungt kinesisk par som sidder tæe ved siden af hinanden. Manden holder parrets nyfødte barn i armene, og begge kigger ømt på det. I baggrunden hænger der en plakat på væggen, hvor der står "Hjælp de nybagte mødre til at amme". Det er et positivt billede, og det fortæller læserne helt præcist, hvad bogen handler om. Denne måde at begynde bogen på er ganske flot, synes jeg.

Der er placeret en vignet i øverste hjørne på den første side i hvert kapitel. Vignetter som disse bliver brugt i Kina til at formidle et-barns politikken, og det er ganske almindeligt, at fødselskontrolmedarbejdere på de kinesiske arbejdspladser og i beboerkomiteer selv tegner sådanne vignetter ud fra de officielle direktiver og dokumenter, som kommer oppe fra. I bogen er brugen af vignetter både illustrativ og hensigtmæssig. Forfatteren fortæller via disse vignetter, hvordan oplysnings- og propagandaarbejdet foregår i fødselskontrolkampagnen, og hvordan et-barns politikken bliver konkretiseret. I hvert kapitel er vignetten velanbragt på den måde, at den passer fint med kapitlets indhold. F.eks. i indledningen, hvor sammenhængen mellem befolkningsstørrelse og økonomisk vækst bliver præsenteret, bruger forfatteren en vignet om "Befolk- 
ning og Økonomi”. I kapitlet om folks anerkendelse af et-barns politikken står der en vignet, som siger at "Det Gavner Nationen, Folket Og Familien At Et Ægtepar Kun Føder Et Barn”.

Til slut vil jeg runde af med at give bogen min aller varmeste anbefaling. Det er en bog, der vil interessere mange, ikke blot akademikere som beskæftiger sig med Kinas befolkningskontrol, men også et bredt spektrum af læsere, der gerne vil vide noget om og få en dybere forståelse af, hvad etbarns politikken betyder for det kinesiske folk. Samtidig er det en bog om kinesisk kultur, kinesisk tænkemåde og adfærd, kvinders daglige liv, det kinesiske samfund og den måde det kinesiske samfundet fungerer på.

Qi Wang

cand.scient pol., ph.d. 


\section{Kvinden er død. Hurra?}

$\breve{A} U$

ANMELDELSE

Bente Schwartz

Kvinden er død. Hurra?

Kroghs Forlag

156 s., 198,- kr.

ANMELDT AF

Hanne Chone
$D_{\text {å vej ind i år } 2000}$

er et dygtigt, ligestillet individ et menneske uden tydelige kønskarakteristika. Dvs. en androgyn, dobbeltarbejdende, kulturløs person uden ord og fortællinger om sit køn.

Denne dystre fremtidsprognose står at læse i Bente Schwartz nye bog med den i iøjnefaldende titel: Kvinden er død. Hurra? Og den står ikke alene. Bogen er én lang harcelering over det moderne liv i almindelighed og det moderne kvindeliv i særdeleshed. Bente Schwartz, der på bogens flap præsenterer sig selv som en tidligere rødstrømpe, der siden 70erne har bevæget sig i kvinde- og kønskredse, gør sig med denne sidste, i en lang række samfundskritiske debatbøger, til fortaler for noget hun lidt diffust kalder det gode liv.

Al ære værd med det gode formål. Problemet er bare, at mens vi $\mathrm{i}$ bogen får rigtig meget at vide om, hvad det gode liv ikke er, făr vi ikke ret meget at vide om, hvad det er. Og det savner man i allerhøjeste grad en fyldestgørende forklaring på. Det er faktisk forst i det næstsidste afsnit, at vi langt om 
længe får lidt at vide om forfatterens syn på "det gode liv": "Det gode hverdagsliv er i min version et liv, som kønnene lever sammen...i samme rum over...længere tid. I et sådant samvær kan der foregå virkelig kommunikation, hvor både hoved og krop kan tale" (s.137).

I Schwartz' vision er kønnene altså ikke som i hendes dystopi androgyne, dobbeltarbejdende, eller kulturløse personer uden ord og fortællinger om deres køn. Tværtimod. Nøgleordet, i Schwartz' programerklæring om det gode liv, er krop. Og ikke bare krop, men en overidealiseret kvindelige krop. Ifølge Bente Schwartz er "fortællinger om kvinder også fortællinger om kroppe" og om kropsbaseret viden. Med sin bog vil Bente Schwartz slå et slag for den samfundsmæssige relevans i kvinders kollektive erfaringer. Og det vil hun gøre ved at fortælle om "kvinder der bærer livet $\mathrm{i}$ deres livmoder: og dermed de kommende slægter”. Livmoderfeminist! Nej, nej, det er hun ikke, understreger hun. Ej heller er hun ude på "at lave en kult omkring kvinders moderkager". Det eneste hun ønsker er "at gøre kroppen synlig som et muligt center for læring. Og for protest” (s. 130). Og det er jo altstemmen meget godt. Det er bare en skam, at hun ikke gør som skrevet. Det kunne der sikkert være kommet en spændende og engageret bog ud af. For det brænder hun tydeligvis for.

Men Schwartz går i en helt anden retning i sin bog. Hun begiver sig ud i, hvad jeg vil vove at kalde et både reaktionært og nostalgisk (rødstrømpe)opgør med den samlede kvinde- og kønsforskning i Danmark, som hun tydeligvis har et horn i siden på. "I min version af det gode liv skulle kønsforskerne gå ind og perspektivere kønnenes politiske ønsker og krav. Så der kom begreber, konsekvenser og alternativer på bor- det " (s.140). Sådan skriver Schwartz, efter hvis mening kvinde- og kønsforskerne ikke varetager almindelige (hvem de så end er?) kvinders interesser godt nok.

Men der skal ikke herske tvivl om, at det er mod de poststrukturalistiske kvinde- og kønsforskere, Schwartz i særdeleshed hvæsser sin polemiske pen i denne bog. For hvis "kvinden er død", så er det ifølge Schwartz de poststrukturalistiske kønsforskere, der har slået hende ihjel. De udgør, som hun fastslår "en arbejdsgruppe til kvindens endeligt". Så ved vi det! Tilbage står der kun at spørge, hvad eller måske rettere, hvem er det Schwartz må sløre for at fremskrive og stabilisere kategorien "kvinden" som et "genkendeligt" almenbegreb?

Ifølge den amerikanske litteraturkritiker Harold Bloom er enhver stærk læsning en fejllæsning. Ifølge samme Bloom bliver resultatet af en stærk fejllæsning en god læsning, og det hvad enten det nu drejer sig om læsninger af lyrik, kritik eller teori. Havde Bente Schwartz' debatbog været en dristig revisionær fejllæsning af den poststrukturalistiske kønsforskning, så kunne den i bedste fald have repræsenteret en velkommen og slet ikke uvæsentlig anledning til en kreativ dialog mellem en repræsentant for rødstrømpegenerationen og yngre (sikkert også nogle ældre) kvinde- og kønsforskere. Og i værste fald kunne den have repræsenteret en anledning til (endnu) en gab! debat om biologisme versus konstruktivisme. Men bogen er ikke en stærk fejllæsning. Den er faktisk ikke en debat om kvinde- og kønsforskningens status værd. Det lyder mildest talt langt ude, når Schwartz skriver, at de poststrukturalistiske kønsteoretikere over én kam er "en religiøs skare der lader deres tro føre dem længere end deres erfaringer. En samlet flok der er optaget af at opløse virkeligheden" (s.33). Og det lyder mildest talt ikke seriøst, når hun for fuld retorisk udblæsning skriver, at der endnu findes (og jeg citerer in extenso) "uvidende personer, der opererer med myter: Med de kulturelle og rituelle overbygninger om kønnene, som de postmoderne kønsteoretikere ellers har opløst. Disse uvidende personer kan finde på at fortælle historier om det kvindelige og det mandlige. Om yin og yang og om feminint og masku- 
lint. De har gerne kroppe, der ikke skjuler, men snarere afspejler kønnet. Og en del af disse folk går på kurser, der skal lære dem at blive kropslige. Og rigtige mænd. Eller rigtige kvinder. Disse praktikere eksisterer således i en virkelighed, der slet ikke er virkelig. For de opererer med to køn, der slet ikke findes!" (s.44)

Uha da, siger jeg. Det må være rart, at være så sikker i sin sag som Bente Schwartz er i sine udtalelser om det væsentlige i "rigtige mænds og kvinders" kropsnære erfaringer og/eller indlæringsprocesser versus kønsforskernes formynderiske ordgejl. Men med respekt at melde, så står det ikke denne læser helt klart, hvorledes Bente Schwartz selv undgår at lade sig fange i den fælde, hun kalder "formynderisk ordgejl" i ovenstående citat!

Som man sikkert kan ane, er min hovedindvending mod Kvinden er død. Hurra? at den er knyttet til Schwartz' useriøse og superficielle kritik af kvinde- og kønsforskningen. Det er i høj grad problematisk at tale om, at vi har "en kønsforskning der ikke forholder sig til kropsligt relaterede erfaringer af kønsspecifik karakter" (s. 31). Ikke nok med at de forskellige centre for kvindeog kønsforskning på landets universiteter $\mathrm{i}$ stort omfang udbyder kurser, der forholder sig til krop, køn og kropsrelateret viden, dvs. kroppens møde med verden, så er bøger om krop og det kropsligt forankrede subjekt som en sand styrtregn skyllet ind over det danske bogmarked gennem de sid- ste år. Nok kommer mange af disse bøger fra udlandet, men adskillige af dem er også produkter af vore hjemlige kvinde- og kønsforskeres tænkning. Bente Schwartz må virkelig have sat kikkerten for det blinde øje for at overse kvinde- og kønsforskningen indenfor temaet.

En anden grundskavank ved bogen er, at Schwartz med brask og bram vil rehabilitere rødstrømpebevægelsens dogmer. Lad mig skynde mig at medgive, hvad medgives skal: 70ernes rødstrømpebevægelse har i allerhøjeste grad medvirket til at blotlægge forholdet mellem køn og magt, samt kortlægge synlige og skjulte forvrængningsmekanismer i magtens centrale rum. Betydningen af 70ernes rødstrømpebevægelse kan slet ikke fremhæves nok. Men i Schwartz' bog overidealiseres den, og det kan den ikke være tjent med. Så bliver det da først nemt for de yngre generationer, rødstrømpernes sønner og døtre, at få den galt i halsen.

Som før nævnt, hvis forfatterens hensigt med bogen er at tematisere det moderne hverdagslivs møje og kalde til debat om det gode liv, så forekommer det mig, at bogen ville have vundet ved at indeholde mindre snik snak om postmoderne kønsforskere og flere bud på, hvorledes vi i samlet flok kan arbejde på at forandre tingenes sørgelige tilstand. På med handsken Bente Schwartz.

Hanne Chone cand.mag. $\AA U$ 


\section{Rødstrømpebevægelsen fra myte til pensum}

\section{ANMELDELSE}

Drude Dahlerup

\section{Rødstrømperne 1-2}

Den danske Rødstrømpebevægelses udvikling, nytænkning og gennemslag 1970-1985

Gyldendal 1998, København $655+500$ s., 595 ,- kr.

\section{ANMELDT AF}

BENTE GADE

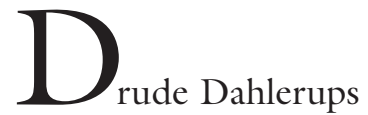

værk om rødstrømperne er et bud på, hvad Rødstrømpebevægelsen egentlig står for. I forhold til så farverig en bevægelse er det lidt af en opgave. Værket er da også en mastodont, men det lykkes faktisk at give et nuanceret billede af den myteomspundne bevægelse. Mest interessant er Dahlerups forsøg på at udrede, hvad der egentligt var nyt, og hvilken effekt bevægelsens radikale kvindepolitik havde. Lad hermed også være sagt, at min egen vinkel på værket kommer fra den etablerede kvinde- \& kønsforskning, og at jeg læser for at få indsigt $\mathrm{i}$ bevægelsens ideologi og dens kønspolitiske strategier.

I Rødstromperne 1-2 analyseres den danske Rødstrømpebevægelse som en social bevægelse, der sigter på at ændre samfundsstruktur, holdninger og adfærd. Dermed gøres den danske Rødstrømpebevægelse til case for samfundsvidenskabelig bevægelsesteori, der kombineres med forfatterens ambition om at afprøve og videreudvikle teorier om sociale bevægelser. Den valgte tilgang er en kombination af ressource-mobiliseringsskolen, der fokuserer på en be- 
vægelses opkomst, udvikling og organisering, samt nyere teorier inden for en social konstruktionstilgang, der fokuserer på selve konstruktionen af nye idéer og betydninger.

Målet er for første gang at beskrive og analysere den danske Rødstrømpebevægelses historie og dens betydning. Dermed håber forfatteren at imødekomme de myter, som har omgivet bevægelsen siden dens start - inklusive deltagernes egne. Bogen behandler tre teoretiske hovedtemaer: bevægelsens livsløb, dens nytænkning og dens gennemslag i det danske samfund. Disse diskuteres ud fra syv hovedspørgsmål fordelt over bogens fem dele med i alt $16 \mathrm{ka}-$ pitler. Denne sindrige konstruktion gør, at argumentationen, trods værkets længde, er klar, men den medfører også en del gentagelser undervejs.

Dahlerup løser problemet med at fremstille Rødstrømpebevægelsens "flade" og dermed foranderlige struktur ved at give en detaljeret gennemgang af bevægelsens udvikling. Den løse organisationsform ser Dahlerup som en væsentlig del af bevægelsens ideologi, og formålet med hendes analyser er at frembringe et fælles verdenssyn fra bevægelsens struktur (autonome basisgrupper som organisatorisk grundprincip), deltagernes handlinger (aktioner, demonstrationer, direkte konfrontation) og anvendte slogans ("Det personlige er politisk", "Ingen klassekamp uden kvindekamp, ingen kvindekamp uden klassekamp”). Mange af rødstrømpernes aktiviteter og slogans er velkendte, men Dahlerup analyserer og diskuterer disse $\mathrm{i}$ forhold til bevægelsen som helhed for at klarlægge en overordnet ideologi. Konklusionen er, at bevægelsen byggede på et fælles verdenssyn, men at deltagerne også manøvrerede blandt indre modsigelser, paradokser og en del uafklarede punkter.

Rødstrømpebevægelsen fremstilles som en ny type feminisme i dansk kvindebevægelses historie med international inspiration. Bevægelsens ideologi betegnes som "kvindefrigørelses-feminisme", hvis mål det er at ændre magtforhold mellem kvinder og mænd i et radikalt anderledes samfund med nye måder at tænke, handle og leve på. Som noget nyt er bevægelsen kun for kvinder, da kvindefællesskab, baseret på den fælles (men forskellige) "kvindeundertrykkelse", anses som nødvendig for at bekæmpe "patriarkatet". Bevægelsen er radikal og en integreret del af venstrefløjen men også en reaktion mod denne idet den sammenkæder klassekamp med en parallel kvindekamp - målet er at vælte det kapitalistiske og det patriarkalske samfund.

Rødstrømpebevægelsens livsløb afgrænses af den første og opsigtsvækkende rødstrømpedemonstration i Danmark den 8 . april 1970 i København og nedlæggelsen af rødstrømpernes kontor i Århus den 8 . marts 1985. Således begrænses Rødstrømpebevægelsens eksistens til 15 år, men bevægelsen sættes ind i feminismens idéhistorie og relateres til hele den nyere kvindebevægelse. Dermed undermineres rødstrømpernes egen tro på, at næsten alt hvad de gjorde og sagde var nyt, samtidig med at der argumenteres for bevægelsens indflydelse på samtid og eftertid. Værkets vigtigste tese er, at der er sammenhæng mellem Rødstrømpebevægelsens radikale feminisme og det væld af kvindepolitiske og kvindekulturelle aktiviteter, der siden har afløst den. Selvom konklusionen er, at Rødstrømpebevægelsen er død, så argumenteres der overbevisende for, at kvindebevægelsen lever.

For at tegne et samlet billede af bevægelsen og samtidig fastholde et indtryk af dynamik og kontinuerlig udvikling opdeler Dahlerup bevægelsens livsløb i tre overordnede faser: Først oprørets fase fra 1970 til ca. 1974 med spontane aktioner og udvikling af nye feministiske ideer. De første aktioner betragtes som en kollektiv læreproces for udviklingen af bevægelsens stil og ideologi. Anden fase fra midten af 1970erne til 1980 betegnes som mangfoldighedens tid med mange nye initiativer, der til- 
sammen udgør en feministisk modkultur centreret om de kvindehuse, der skød op over hele landet. Tredje fase fra ca. 1980 er specialiseringens tid med mange forskellige og uafhængige initiativer og den begyndende professionalisering, der leder til bevægelsens ophør.

Bevægelsens udvikling fremstilles som et gradvis skift fra revolutionær retorik og protest til reformpolitik i form af konkrete krav og samarbejde med andre kvindeorganisationer. Ud over at beskrive "hvordan" bevægelsen forandrede sig, gives der også et interessant bud på "hvorfor"; bevægelsens politik ændredes på grund af en dynamik mellem ydre faktorer, krisetider og venstrefløjens generelle vending mod reformpolitik og indre faktorer; erfaringer, udvikling af nye ideer og interne stridigheder, samt deltagernes eget livsforløb. Fordi deltagernes engagement ses som bevægelsens vigtigste resurse, gør Dahlerup en del ud af at påvise en sammenhæng mellem deltagernes eget livsløb og bevægelsens udvikling ved hjælp af en rundspørgeundersøgelse blandt tidligere rødstrømper. Rødstrømpeenqueten er interessant på mange måder, og Dahlerups diskussion af resultatet gør de statistiske oplysninger både spændende og nuancerede. Enqueten bruges bl.a. til at påpege, at der er sket en tilnærmelse mellem de radikale rødstrømper og den brede befolkning. Dermed konkluderer Dahlerup, at det ikke var nye medlemmer, der ændrede bevægelsens politik, men deltagerne selv som begyndte at støtte den ligestillingsfeminisme, de tidligere var modstandere af.

Til analysen af rødstrømpebevægelsens indflydelse på det danske samfund udvikles begrebet "nytænkning". Nytænkning skal forstås som både tanker og praksis: nye måder at tænke og handle på. Ifølge Dahlerup var rødstrømpernes vigtigste nytænkning opfattelsen af kvinder som en gruppe. Et godt eksempel på hvordan rødstrømperne ændrede diskursen, dvs. måden hvorpå kvinders forhold blev diskuteret, er abort- sagen, idet abort ændredes til et spørgsmål om kvinders ret til at bestemme over egen krop. I forhold til praksis argumenterer Dahlerup for, at rødstrømpernes egen optræden i det offentlige rum var særdeles betydningsfuld. Ved aktioner og demonstrationer repræsenterede rødstrømperne selv en ny, selvstændig kvinde-identitet. En interessant tese hos Dahlerup, der understøttes af Rødstrømpe-enqueten, er netop, at bevægelsen rekrutterede nye medlemmer via identifikation med denne kvindetype.

Når en bevægelses evne til at tænke og handle på en ny måde ses som dens væsentligste samfundsforandrende kraft, så bliver gennemslaget for denne nytænkning afgørende i forhold til bevægelsens succes. Nytænkning ændrer således bedømmelsen af en bevægelse fra en sammenligning mellem bevægelsens erklærede mål og opnåede resultater til en bedømmelse af gennemslag for bevægelsens nytænkning. Nytænkningstilgangen gør altså Rødstrømpebevægelsens evne til at påvirke den officielle dagsorden til en vigtig faktor. Dahlerup argumenterer da også for, at rødstrømperne netop, ved brug af utraditionelle og provokerende metoder, var gode til at sætte kvindespørgsmål på den officielle dagsorden. Hun tildeler dermed bevægelsen en stor del af æren for den voksende opmærksomhed omkring kvinders vilkår og den stigende politiske mobilisering af kvinder, idet bevægelsen gjorde køn til en væsentlig, selvstændig kategori.

Social konstruktionsteori, der sætter fokus på selve konstruktionen af nye betydninger og nye identiteter, viser sig som en effektiv tilgang, der kan fremanalysere en social bevægelses betydning og samfundsforandrende kraft. Nytænknings-tilgangen gør det muligt at argumentere for, at rødstrømperne radikaliserede den eksisterende ligestillingspolitik. Således sammenkæder Dahlerup den radikale kvindebevægelse uden for de politiske organisationer med den ligestillingspolitik der føres indenfor. Hendes konklusion er da også, at Rød- 
strømpebevægelsen havde betydelig gennemslag i samtiden og omfattende langsigtede virkninger. Dahlerups tilgang er yderst spændende men problemet er, at de reelle sammenhænge er svære at påvise. Dahlerup bruger effektivt "ringe i vandet" som metafor for bevægelsens udbredelse, men jeg savner en klarere udredning af sammenhænge mellem bevægelsens diskurs og den officielle. Måske spiller det en rolle, at vær- ket er skrevet af en insider således, at der ikke gøres så meget for at understøtte forbindelser, der forekommer oplagte.

Dahlerup nævner selv og ikke uden nostalgi, at Rødstrømpebevægelsen er blevet til pensum. Med dette vark har hun sørget for, at der findes et vægtigt bidrag til pensum om den danske Rødstrømpebevægelse. Bente Gade cand.mag., $K U$ 


\section{Uddannelses- planlægning som ligestillingsredskab

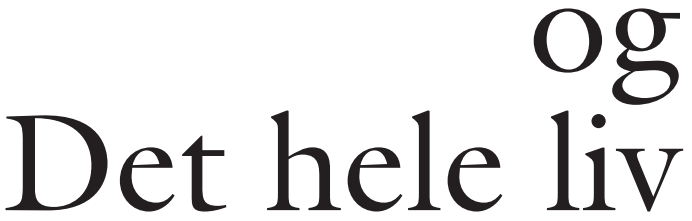

\section{BOGOMTALE}

\section{Uddannelsesplanlægning som ligestillingsredskab}

Arbejdsmarkedsstyrelsens arbejdsnotat nr. 29 1998, $87 \mathrm{~s}$.

Fås ved henvendelse til Arbejdsmarkedsstyrelsen

\section{Det hele liv}

Kvindeligt Arbejderforbunds uddannelsesindsats 1985-1997, 159 s.

Fås ved henvendelse til Kvindeligt Arbejderforbund

\section{Af Gerda Thorsager}

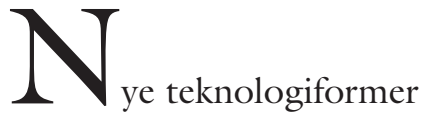

og organisatoriske forandringer samt flere servicebetonede opgaver stiller nye krav til kvalifikationer og kompetence til medarbejderne rundt om på arbejdspladserne. Arbejdsmarkedstyrelsen har i et forsøgsprojekt kombineret uddannelse med ligestilling, og Kvindeligt Arbejderforbund satte uddannelse til medlemmerne på dagsordenen i 1985 i forbindelse med prognoserne om høj arbejdsløshed blandt kvinder. Uddannelse skulle bruges til opkvalificering, mere ligestilling og et bedre liv i det hele taget.

Arbejdsmarkedsstyrelsens (AMS) forsøgsprojekt blev gennemført i samarbejde med tre fynske virksomheder over en periode på $21 / 2$ år. Formålet med projektet var dels at fremme det virksomhedsvendte ligestillingsarbejde og dels at bidrage med redskaber, der kan nedbryde kønsbestemte barrierer på arbejdsmarkedet og i den enkelte virksomhed.

Virksomhederne var en offentlig virksomhed samt to private, og der blev gennemført interviews med i alt ca. 500 medarbejdere i de fire delprojekter, som for- 
søget omfattede. Gennem interviewene blev medarbejdernes job- og kvalifikationsprofiler kortlagt samt deres behov og ønsker til udvikling. Der blev desuden lavet en anonym interviewdel, hvor der blev spurgt om holdninger til og oplevelser af forskellige sider af arbejdssituationen.

Projektet skulle munde ud i et forslag til uddannelse og forslag til handlingsplan for ligestilling. Den væsentligste del af handlingsplanen var de individuelle udviklingsog uddannelsesplaner. Derudover blev handlingsplanen suppleret med tværgående ligestillingsaktiviteter. Det var f.eks. aktiviteter, som betød ændringer i arbejdsorganiseringen, kommunikationsrutiner, særlige kurser om samarbejde mellem mænd og kvinder og foredrag om ændringer i holdninger og kulturer i organisationer.

Uddannelserne kunne bestå i interne og eksterne kurser, jobtræning, følordninger og længerevarende uddannelsesforløb eller udvikling af specialtilpassede kurser til en gruppe af medarbejdere.

Det var forskelligt, hvordan virksomhederne greb aktiviteterne an, men fælles for virksomhederne var, at de blev mere bevidste om at tilgodese de medarbejdere, der tidligere har været tilbageholdende. I forhold til uddannelse blev det synligt, at undervisningsstederne og underviserne ikke tænker i ligestillingsbaner, hvilket var en barriere $\mathrm{i}$ forhold til projektets målsæetning på ligestillingsområdet.

Arbejdsnotatet indeholder bilag med eksempler på jobprofiler, medarbejderprofiler og det anonyme spørgeskema, der blev anvendt $\mathrm{i}$ den anonyme del af interviewene samt en ekspertvurdering af de benyttede metoder i projektet.

\section{"Det hele liv", Kvindeligt Arbejderforbunds uddannelsesindsats 1985-1997 er en beskri- velse af forbundets strategier og indsats, si- den uddannelse kom på den politiske dags- orden ved Kvindeligt Arbejderforbunds (KAD) kongres i 1985. Bogen er bygget}

op omkring kongresbeslutningerne om uddannelse i perioden 1985 til 1997, og hvordan beslutningerne blev gennemført.

I de første forsøgsprojekter var det de arbejdsløse medlemmer, der skulle sættes ind over for. I kontakt med de arbejdsløse blev der sat uddannelsesforsøg i gang i Vejles og Fyns Amter. Der blev sat alternative forsøg i gang, fordi det viste sig, at specialskolerne manglede kvindelig pædagogisk erfaring. Specialskolerne havde lang erfaring med at undervise kortuddannede mænd, men ikke kortuddannede kvinder.

På kongressen i 1991 blev det besluttet, at uddannelsesindsatsen også skulle rettes mod de beskæftigede med kurser, der var kompetencegivende $\mathrm{i}$ forhold til specifikke erhvervsområder. Nye arbejdsformer kom dermed ind i billedet samtidig med, at der på lovgivningsområdet blev sat gang $\mathrm{i}$ en række arbejdsmarkeds- og uddannelsesreformer. I 1994 skulle der gøres en ekstra indsats $\mathrm{i}$ forhold til at styrke medlemmernes interesse og mulighed for at tage en egentlig kompetencengivende erhvervsuddannelse. Den videre udvikling kom også til at omhandle og udvikle uddannelser på nye områder såsom serviceassistentuddannelserne, herunder Grøn Hjemmeservice, multimedieuddannelsen o.a.

Det beskrives, hvordan struktureringen og organiseringen af uddannelsesarbejdet har fundet sted, og hvilke organer, der kom til at præge arbejdet, samt de muligheder lovgivningen åbnede for. Med hensyn til fremtiden går KAD's overvejelser på, hvilken betydning det vil få, at kun et fåtal af medlemmerne vil være ufaglærte i traditionel forstand i fremtiden i henhold til målsætningen, og om der bør åbnes for medlemskab for andre faglærte kvindegrupper. Det er de åbne spørgsmål og fremtidens udfordring for Kvindeligt Arbejderforbund.

Bogen er rigt illustreret med grafik. Gerda Thorsager $K U$ 